\title{
Agreeing and Impacting: The Effect of the Shareholders' Agreement on Firms' Market Value
}

\author{
Andre Leonardo Pruner da Silva ${ }^{\dagger}$ \\ Fundação Getulio Vargas \\ Jeferson Lana $\Omega$ \\ EAESP-FGV \\ Rosilene Marcon ${ }^{\ddagger}$ \\ Universidade do Vale do Itajaí
}

\section{ABSTRACT}

Some countries admit the presence of pacts that allow to change the relations and balance of power control exercised by the shareholders. Known as shareholder agreements, these pacts are contracts between two or more partners whose goal is to agree on the direction of the relationship between its members. Empirical results suggest that shareholder' agreements play an important role in low legal protection markets because they inhibit the ability of the majority shareholder to extract benefits in detriment of minority shareholder. This paper aims to analyze the effect of shareholders' agreements in the market value of Brazilian companies from 1999 to 2013 . The sample is composed by 472 companies, including 86 companies with shareholder' agreements. The empirical strategy comprises the fixed effects method on a panel data model. The results show that the effect on firm value is positive as the degree of protection of minority shareholders is higher. However, the regressions tested with the indirect ownership structure have not been able to provide evidence to that effect.

Keywords: Shareholders' agreement; Corporate governance; Ownership structure.

\section{INTRODUCTION}

Formalized by means of the Brazilian Law of Corporations, in 1976, and widely used by Brazilian companies, shareholders' agreements (SAs) are pacts concluded between two or more shareholders, whose goal is to agree on the direction of the relationship between its members.

They can thus act, in a way that strengthens corporate governance mechanisms, mitigating the expropriation of minority signatories to these agreements, but they may also intensify agency problems.

SAs are anchored in two pillars: the first of them regulates the transfer of shares between the partners agreed and aims to preserve the way in which power is distributed. The second is the commitment, the anticipated and directed convention of the positioning of a group of shareholders within the company. These agreements seek to maintain or obtain control of the firm, or even the agglutination of votes, in defense of minority shareholdings (CARVALHOSA, 2003).

Corresponding author:

${ }^{\dagger}$ Fundação Getulio Vargas

E-mail: andrepruner@gmail.com

$\Omega$ EAESP-FGV

E-mail: jeferson.lana@gvmail.br

${ }^{¥}$ Universidade do Vale do Itajaí

E-mail: rmarcon@univali.br

Received: 06/28/2016. Revised: 08/18/2016.

Accepted: 11/24/2016.

Published Online: 08/01/2017. 
From the classic perspective of corporate governance (CG) - "principal/agent" (P/A), the solution to the problems arising from the ownership structure would be the employment of contractual incentives and the monitoring of the agents that participate in the management of the firm. However, the CG model, initially proposed based on the scenario of AngloSaxon countries, whose more developed institutional context guarantees greater legal applicability, is in itself inadequate to portray different institutional structures (LA PORTA et al,,1997). In other words, countries with low legal protection are characterized by highly concentrated ownership structures (OS) (LA PORTA et al., 1997).

This paradigm shift, whose conflict focus is associated with the different shareholders that make up the OS - "principal/principal" $(\mathrm{P} / \mathrm{P})$, is generally associated with the possibility of the controller expropriating minority value by retaining the firm's own benefit (JOHNSON et al., 2000). Thus, majority participation in OS tends to generate benefits not shared with other partners (CLAESSENS; DJANKOV; LANG, 2000; LA PORTA et al., 2002).

SAs are inserted in this context. Empirical research suggests that this instrument can act as a reorganizer of power among the shareholders that make up the OS. In order to correct extreme situations, that is, when the degree of concentration is high, it can be used to limit voting power (BAGLIONI, 2011). Although power distributor Eletropaulo in 2009 owns AES Elpa as majority shareholder with $77.8 \%$ (commom shares - ON) of control, this shareholder is a signatory of a SA with a minority - BNDESPAR - whose participation in common shares is $0 \%$, and the total participation is $4.4 \%$. In other words, AES Elpa relinquishes its absolute control by means of a contract that establishes certain rights to BNDESPAR. Among these rights, the members of the board of directors linked to the agreement exercise their votes in accordance with what was pointed out by BNDESPAR in a previous meeting. Thus, a minority investor, without common shares, is able to have his interests taken into account in the firm's decisions.

On the other hand, such agreements may indirectly alter the OS of firms with dispersed capital. For example: The All América Logística, in 2009, has a OS with a pulverized characteristic whose most relevant shareholder holds $19.20 \%$ of the control. However, when considering the total participation formed by the group of shareholders linked to the SA, this participation totals $66.5 \%$. Therefore, a group of 9 shareholders with minority interests indirectly obtains control of the firm.

In line with this argument, Volpin (2002) obtained empirical results indicating that the dismissal of managers whose performance was unsatisfactory is more frequent when there is a block of shareholders, formed by SAs, capable of challenging the control.

The statistical results found by Carvalhal (2012) suggest that this reorganization of power, pointed out by Baglioni (2011), is associated with the presence of clauses guaranteeing rights to minority shareholders linked to the agreement, i.e., that mitigate the ability of control holders to expropriate them for their own benefit. Thus, the greater the effectiveness of the agreement in restraining conflicts, the greater the positive effect on firm value.

In emerging markets, such as the Brazilian, whose institutional impact is not stable and easily measured, the mechanisms of corporate governance do not have an effective and reliable legal system, creating an unfavorable environment for shareholders who do not hold firm's control (YOUNG et al., 2008). In this context of low legal protection, given the intense frequency with which companies have the use of shareholder agreements, Brazil is a natural barn capable of providing the opportunity for understanding the possible consequences of this mechanism on the value of the firm. Although some research has highlighted the existence of these pacts in many Brazilian companies (SILVA, 2004; LEAL, SILVA, 2008), little was actually analyzed about its possible implications when the focus of the investigations was the OS.

The theory shows two views on shareholder agreements. The first is associated with empirical results that attribute its positive effect on firm value to the redistribution of power, 
BBR

15,1

90

or put better, to its balance through bonded shares (VOLPIN, 2002; ROOSENBOOM; SCHRAMADE, 2006; BELOT, 2008; VILLALONGA; AMIT, 2009; BAGLIONI, 2011). The second attributed this effect to the characteristics of these agreements. Specifically, when it is associated with clauses that seek to mitigate the retention of results of the firm for the benefit of the controlling shareholder (CARVALHAL, 2012).

Thus, this article aims to analyze the effect of shareholder agreements on the market value of Brazilian publicly traded firms, traded on the BMF\&Bovespa from 1999 to 2013.

The improvement of these investigations will contribute to the development of the stock market and corporate governance from the practical point of view. While there is empirical evidence that shareholder agreements can be viewed negatively by investors (GIANFRATE, 2007), this article starts from the intuition that such agreements, when associated with mechanisms that strengthen $\mathrm{CG}$, generate long-term benefits to shareholders (CARVALHAL, 2012). Therefore, these results would help demystifying the existing negative association, as well as encouraging the incorporation of mechanisms that, in fact, align the interests between majority and minority shareholders.

Moreover, based on these empirical evidence, this research can theoretically contribute by analyzing the effect of these agreements, taking into account their capacity to mitigate expropriation, as well as reorganizing the relationships among the various shareholders through related shares, in the formation of control blocks. Therefore, we used the quality index of the SAs termed as the shareholder agreement index (SAI) to measure this effect, developed by Carvalhal (2012), as well as direct and indirect variables (related shares) of ownership structure. That is, we sought to investigate whether the mitigation of the expropriation of minority shareholders occurs through the reorganization of power among the shareholders or the content addressed in these agreements.

For this purpose, a sample of 472 listed companies, not belonging to the financial and funds sector, where 86 of these companies held a shareholders' agreement within the analyzed period. The empirical strategy included the fixed effects method for panel data.

In addition to this brief introduction, this article is organized into five parts. The next chapter seeks to contextualize, generally speaking, the theoretical framework that served as a foundation for the development of the research. Next, we highlighted the proposed research hypotheses. Subsequently, the methodological aspects stand out. In the last section we present the results and discussions of the models. Finally, references are presented.

\section{THEORETICAL FRAMEWORK}

\subsection{CORPORATE GOVERNANCE}

The scholarly discussion of the separation of ownership and control was first approached by economist Adam Smith in 1776. However, empirically the theme was tested only more than a century later. The article titled as The Modern Corporation and Private Property is considered seminal to corporate governance. In their work, Berle and Means (1932) empirically disagree about the dispersion of US corporate ownership, so that this characteristic would increase managers' propensity to act in accordance with their interests.

These results served as the basis for the development of the agency theory, by Jensen and Meckling (1976). From this point of view, the firm would be formed by legal fictions, specifically by implicit and explicit contractual relationships, signed between individuals (FAMA; JENSEN, 1983). This is the essence of the agency theory. These mutual contracts between agents, characterizing market relations, are grounded within firms by contractual systems that define the organizational "game rule" (JENSEN, 1983).

Therefore, the agency relationship is defined by Jensen and Meckling as a contract, whose principal delegates to the other person, the agent, the function of managing the firm 
on their behalf (JENSEN; MECKLING, 1976). This definition is based on the existence of conflicting interests between them. The solution to the agency problem would be the use of contractual incentives, as well as agent monitoring. Therefore, corporate governance (CG) was developed.

Based on the problem of the separation of ownership and control, CG is formed by a series of "constraints" that agents impose on themselves, or that investors impose on them in order to reduce the misallocation of resources (SHLEIFER; VISHNY, 1997). These "constraints" pointed out by Shleifer and Vishny (1997) were described by Denis and McConnell (2003) as a set of mechanisms that encourage the agent to make decisions in order to maximize the firm's value to the principal. This work, therefore, assumes this definition, classifying the mechanisms of CG in two groups: internal and external mechanisms. These are formed by the Hostile Acquisitions Market and the Legal and Regulatory System. Those are subdivided into: Board of Directors and Ownership Structure. Above all, the focus of this work falls specifically on the ownership structure and the legal and regulatory system.

\subsection{OWNERSHIP STRUCTURE}

Based on the findings by Berle and Means (1932), many studies devoted themselves to investigating this topic. Especially, the article developed by Jensen and Meckling (1976) formulated the incipient propositions concerning the agency relationship between managers and the owners of the firm. Through their analysis, the authors sought to identify the maximum and minimum levels of agency costs associated with the superfluous benefits enjoyed by the agent.

We can observe in this research that the literature acknowledges the existence of advantages and disadvantages related to the degree of concentration of ownership of firms. The presence of a controlling shareholder can sometimes have benefits because, as the principal has a large percentage of control, agency problems resulting from the free rider effect would not exist (SHLEIFER; VISHNY,1986; SHLEIFER; VISHNY,1997; CLAESSENS; FAN, 2002; DENIS; MCCONNELL, 2003). These benefits are referred to in the literature as "incentive effect".

On the other hand, although excessive control is efficient, in order to mitigate agency problems between principal and agent, large shareholders have their own interests. These motivations do not always coincide with the goals of other shareholders (SHLEIFER; VISHNY,1997). In view of this fact, agency conflicts are mainly associated with conflicts between the controlling shareholder and minority shareholders (LA PORTA; LOPES-DESILANES; SHLEIFER, 1999; 2002; DENIS; MCCONNELL, 2003). This negative effect is called by the literature as "entrenchment effect".

These characteristics of OS are important when legal protection is not able to ensure that the interests of the principal are taken into account in the decisions taken by the agent (LA PORTA; LOPES-DE-SILANES; SHLEIFER, 1999). Thus, the internal and external mechanisms work in an integrated way, that is, it affects and is affected by the other.

\subsection{LEGAL AND REGULATORY SYSTEM}

The corporate governance model developed by Jensen and Meckling (1976), Under the perspective of more developed institutional contexts that guarantee greater legal applicability, by itself is not able to portray CG in different institutional contexts (LA PORTA et al.,1997). In other words, CG mechanisms are affected by the degree of legal protection, as well as by ensuring the applicability of laws in defense of shareholders and creditors (SHLEIFER, VISHNY, 1997).

Empirical evidence points to an inverse relationship between the degree of legal protection and the level of concentration of OS. In other words, countries with low legal 
BBR

15,1

92

protection are characterized by highly concentrated ownership structures, as well as by less developed stock markets (LA PORTA et al.,2000). This concentration aims at balancing the absence of legal protection (LA PORTA et al.,1997).

In addition, this control is often guaranteed through indirect structures such as: crossparticipation, pyramids, formation of blocks through SAs and the issuance of two types of shares that separate the right of control and the right over cash flow (LA PORTA; LOPESDE-SILANES; SHLEIFER, 1999; CLAESSENS, DJANKOV; LANG, 2000; CLAESSENS et al., 2002).

In this regard, shareholders' agreements are pacts signed between two or more partners, whose purpose is to formalize the relationship between them. They can therefore act in a way that strengthens governance mechanisms, mitigating the expropriation of minority shareholders, protecting the interest of those who hold the smallest share of capital, in addition to adding agency problems.

\subsection{SHAREHOLDERS' AGREEMENTS}

In Brazil, Law 6.404/76, termed as the Brazilian Corporate Law, understanding the contumacious occurrence of concluding the SAs, was one of the first to deal directly with this matter. Its main objective was to avoid excesses practiced through these contracts (FILHO, 2001; CARVALHOSA, 2003). In addition, with the amendment conferred by Law 10.303/01, which expressly included the term "power of control", the prerogative of formation of voting in block was established, that is, of the relation of shares held by various shareholders. This characteristic is similar to pooling agreements in the US market. By virtue of this prerogative, one or more shareholders undertake to hold a prior meeting, where they agree among themselves, by the decision of the absolute majority, the direction of the votes that will be held in a general meeting.

Thus, these pacts are anchored under two main objectives. The first, called a blocking agreement, seeks to regulate the purchase and sale of shares, or its acquisition by priority by those who are contracted under this instrument. Generally, these prerogatives impose restrictions on the sale of the agreed shares to third parties without the consent of the other parties, or even the right of preference on purchase (CARVALHOSA, 2003).

The second, the voting agreement, aims to discipline (SILVA, 2005) or compromise the vote in advance (CARVALHOSA, 2003), guaranteeing the maintenance or the attainment of the control of the firm, or in defense of minority shareholders. Therefore, they are characterized by voting agreements, when they aim at linking a group of shareholders, forming a block of shareholders with the purpose of ensuring that their power is maintained.

Therefore, shareholder agreements are capable of indirectly changing the relationship between ownership control and control over cash flow, independently of the emission of two types of actions, as well as the use of pyramids that aim at maintaining or obtaining control (VILLALONGA; AMIT, 2008), thus altering the proportionality of a share (ON) one vote (BAGLIONI, 2011). Therefore, accompanied by the theoretical basis from which they were derived, we present the hypotheses that the research proposes to answer.

\section{RESEARCH HYPOTHESIS}

Given that corporate governance mechanisms, especially the ownership structure, are impacted by the country's level of institutional protection (LA PORTA et al.,1997), conflicts of interest, as pointed out by the agency theory, in markets with low legal protection, occur from the perspective of majority and minority shareholders (SHLEIFER, VISHNY, 1997; LA PORTA et al.,2000).

This influence of the institutional context on the internal mechanisms of CG emphasizes the need to explore this theme even more, especially the impact of the contract agreement, 
capable of indirectly altering, as well as the balance of power of control exercised by the shareholders in $\mathrm{CG}$ through the bonding of shares and in the formation of shareholder blocks (VILLALONGA; AMIT, 2008). In this regard, empirical results obtained by Volpin (2002) suggest greater sensitivity to the dismissal of executives with poor performance when there is a block of shareholders, formed through the agreements, capable of contesting control.

Roosenboom and Schramade (2006) investigated the effect of the agreements in a sample of French firms that performed IPO, so that the presence of these agreements is positively related to the market value of the firm after the subscription. Belot (2008) also confirms this relationship, pointing out that the negative effect of the control exercised by large shareholders impacted on the value of the firm tends to disappear when there is a control block formed through the agreements.

Villalonga and Amit (2009) Perceived that the companies whose control is owed by families are the ones that use the most indirect control, by means of corporate pyramids, issuance of non-voting shares and shareholders' agreement, so that the latter has a positive relation with the firm's value, i.e., it decreases the entrenchment effect. These results are in line with the argument that the agreements can act as reorganizers of power among the shareholders that make up the firm's OS. In order to correct extreme situations, i.e., when concentration is high, they can be used to limit voting power. On the other hand, they can strengthen shareholders with inexpressive shareholdings (BAGLIONI, 2011). Based on this, the first research hypothesis is developed as follows:

\section{H1 - When considering the structure of indirect ownership, formed by means of bonded shares actions, shareholder agreements have a positive impact on the market value of firms.}

On the other hand, developing a more robust analysis of SAs, through the quality index termed as SAI, the results found by Carvalhal (2012) suggest that the greater the presence of clauses guaranteeing rights to minority shareholders, i.e., which mitigate the ability of control holders to expropriate them for their own benefit, the higher the market value of the firm. This point of view is consistent with the argument by Chemla et al. (2007), for which shareholder agreements play an even greater role in markets with low legal protection with concentrated OS, since they inhibit the ability of the largest shareholder to extract private benefits against minority shareholders. From these empirical and rational theoretical results, therefore, we derive the second research hypothesis:

\section{H2 - Shareholders' agreements with minority protection clauses positively impact the market value of firms.}

Thus, this paper aims to broaden the understanding of the capacity to reallocate power through agreements, as the ownership structure is altered, as well as it seeks to understand whether their quality, in the sense of reducing the expropriation, is capable of causing the increase of the value of the firm.

\section{METHODOLOGICAL ASPECTS}

\subsection{SAMPLE AND DATA COLLECTION}

The data we used in this study are secondary in nature. The sample comprises the Brazilian publicly traded companies traded on the BMF\&Bovespa. In addition, due to the particularities of the capital structure and its indicators, we excluded companies from the financial and fund sector, as well as observations related to firms that presented negative 
BBR

15,1

94

shareholders' equity in the respective period. Such measures aim to standardize the data, in search of more consistent results.

The longitudinal dataset comprises the period from 1999 to 2013. Therefore, the final sample is comprised of a total of 472 companies, which are not necessarily present throughout the analyzed period.

Due to the lack of information in a single database, we carried out the collection in three different databases. The first of these was the External Disclosure System (DIVEXT), from where we downloaded the respective files corresponding to each company surveyed in the period from 1999 to 2008. The year of 2008 is the last with data available in this base. Regarding the data referring to the period from 2009 to 2013, we extracted these from the Economática database and the BMF\&Bovespa website. It should be noted that, although the bases are different from each other, the data are consistent, since the source of the data is common for all. With regard to the collection of data on shareholder agreements, we decided to use the CVM website (equivalent of the American Securities and Exchange Commission - SEC). We extracted the economic-financial data of the companies from the Economática database in dollarized values, using as the reference rate the PTAX dollar quotation of January 2, 2014.

\subsection{VARIABLES}

We selected the market-to-book as the dependent variable. we are dealing with a measure used in some studies that sought to identify the effect of the characteristics of OS and SAs on firm value (THOMSEN; PEDERSEN, 2000; CLAESSENS et al., 2002; DOUMA et al., 2006; CARVALHAL, 2012). The operationalization of the variable is presented in Table 1.

Table 1. Dependent variable

\begin{tabular}{|ccc|}
\hline Variable & Code & Formula and description \\
\hline Market-to-book & mkbook & Market to book $=\left(\frac{\text { Total Book Value }}{\text { Toral Market Value }}\right) \times 100$ \\
\hline
\end{tabular}

Source: Prepared by the authors

As for the predictor variables, the presence of shareholder agreements was represented by a dummy variable. In addition, in order to verify the effect of the quality of these agreements on the firm's market value, and taking into account the complexity of contracts, we used the shareholder agreement index (SAI), developed by Carvalhal (2012). The SAI is measured by the presence of clauses capable of benefiting the minority shareholders, preventing the occurrence of the entrenchment effect. It is composed of 24 questions, and each can be answered by "yes" or "no" (the questionnaire used to construct the index is inserted in Annex A), so that at each "yes" the indicator would compute 1 point, and 0 for each "no". Therefore, this index can range from 0 to 24 points. In addition, we tested each of the five dimensions that make up the SAI independently, as a predictor variable. Table 2 provides a brief description. 
Table 2. Predictive variables

\begin{tabular}{|c|c|c|}
\hline Variable & Code & Description \\
\hline Agree & agree & $\begin{array}{c}\text { Dummy type variable; (1) when the company has a shareholders agreement, and (0) when it } \\
\text { does not. }\end{array}$ \\
\hline Shareholder Agreement Index & sai & The indicator that measures the total quality of shareholder agreements. \\
\hline Transfer of shares & act & The first dimension consists of clauses that impose restrictions on the transfer of shares. \\
\hline Dividend & acd & $\begin{array}{l}\text { It concerns the clause that prevents the unjustifiable reduction of dividends paid to minority } \\
\text { shareholders. }\end{array}$ \\
\hline Investment & $a c i$ & $\begin{array}{l}\text { The investment dimension is associated with restrictions on undertaking investments that meet } \\
\text { the objectives of the firm. }\end{array}$ \\
\hline Financing & acf & It consists of clauses restricting excessive debt. \\
\hline Corporate Governance & $\operatorname{acgc}$ & $\begin{array}{l}\text { The last dimension is made up of clauses that directly strengthen the mechanisms of corporate } \\
\text { governance, as well as provisions associated with negative aspects. }\end{array}$ \\
\hline
\end{tabular}

Source: Developed by the authors

With respect to the control variables of the ownership structure, the direct participation of the shareholders is represented by the voting shares (common shares) and total (rights over cash flow) held by the largest shareholder. The indirect holdings, formed by the block of related shares, were also considered when they represent a higher percentage than the direct participation. Thus, Table 3 briefly describes these variables.

Table 3. Ownership Structure Variables

\begin{tabular}{|c|c|c|}
\hline Variable & Code & Description \\
\hline Voting Rights of the Major Shareholder. & vot & $\begin{array}{l}\text { It represents the direct participation with voting rights of the } \\
\text { largest shareholder. }\end{array}$ \\
\hline $\begin{array}{l}\text { Indirect participation with voting rights of the Members } \\
\text { of the Shareholder Agreement }\end{array}$ & avot & $\begin{array}{l}\text { It represents the indirect participation with voting rights of the } \\
\text { group formed by related shares in the shareholders' agreement. }\end{array}$ \\
\hline
\end{tabular}

Source: Developed by the authors

To control the interferences of other variables in the model, we selected a series of additional control variables from the study by Carvalhal (2012). In addition, based on Silveira (2004), we decided to use the issuance of ADRs to control differentiated corporate governance standards of firms and, finally, we used the annual variation of IBOVESPA to control the effect of market behavior on the dependent variable. (A summary of this selection is presented in Table 4).

Table 4. Control Variables

\begin{tabular}{|c|c|c|}
\hline Variable & Code & Description \\
\hline Size & Ltotassets & $\begin{array}{l}\text { It corresponds to the logarithm of total assets, measured in thousands } \\
\text { of dollars. }\end{array}$ \\
\hline Return on Total Assets - ROA & ROA & $\begin{array}{l}\text { It indicates the firm's profitability as a function of total assets. } \\
\qquad \text { ROA }=\frac{\text { Net Profit }}{\text { Total Asset }}\end{array}$ \\
\hline Indebtedness & Leverage & $\begin{array}{l}\text { They reflect how much companies have taken third-party capital in } \\
\text { function of the equity. } \\
\qquad \text { LEVERAGE }=\frac{\text { Total Liabilities }}{\text { Net Worth }}\end{array}$ \\
\hline Issuance of ADRs & $\mathrm{ADR}$ & $\begin{array}{l}\text { Dummy variable; If the company has a double listing in the North } \\
\text { American market, the variable receives the value } 1 \text {, otherwise } 0 \text {. }\end{array}$ \\
\hline Variation of Ibovespa & Ibovespa & Percentage variation of IBOVESPA. \\
\hline
\end{tabular}

Source: Developed by the authors 
BBR

15,1

96

As reported by Carvalhal (2012), companies with Shareholder Agreements tend to be larger (Size) and more leveraged (Indebtedness). The same goes for performance (ROA). Thus, a positive correlation between the variables of control and SA is expected, either by the presence (agree) or its typology (SAI). Finally, as the hypotheses point to a positive relation between SA and market value, the same is expected for the control variables. Regarding the issue of ADRs, according to Silveira (2004), developed corporate governance mechanisms may be associated with the increase in firm value. Therefore, we decided to control this issuance in accordance with the differentiated standards of corporate governance that are required in the international market (SILVEIRA, 2004); we expect, therefore, for the effect of the more developed OS mechanisms to be controlled.

\subsection{PROPOSED MODELS}

Considering the challenges inherent to the research problem, regarding the empirical strategy, we opted for the multivariate linear regression with Fixed Effects (FE) and panel data.

Model 1 seeks to test the first research hypothesis, i.e., if the effect of the shareholders' agreements on the firm's value is associated with the redistribution of the power provoked through the indirect OS formed by the bonded shares in the shareholders agreements. This relationship is measured by the interaction between the variable agree and avot.

Posteriorly, Hypothesis 2 is tested using the variable that captures the presence of shareholders' agreements (agree) and, more profoundly, by the indicator SAI. The objective of these two variables is to verify whether the effect on value is attributed to the ability of SAs to mitigate the majority shareholder's expropriation of minority shareholders as discussed in the hypothesis formulation.

As for the second model, two characteristics differ from the previous one. First, we tested each of the five dimensions (act, acd, aci, acfe e acgc) independently, and then together, i.e., a test for each of them and the five dimensions at once. We sought, therefore, to present an alternative empirical model, which aimed to give more robustness to the analyzes carried out.

To ensure the robustness of the models and to mitigate econometric problems common to the quantitative estimates, we took some preventive actions. First, we performed the tests using consistent coefficients of heteroscedasticity (Eicker-Huber-White). In addition, we tested multicollinearity with the aid of the Variance of Inflation Factor (VIF), with rejection for models with VIF above 10.0. Test Procedures on Non-Stationary Variables (IM; PESRAN; SHIN, 2003; HLOUSKOVA; WAGNER, 2006) were performed from Stata software routines. Finally, we analyzed the residues for evidence of non-linearity or bias. We performed all tests with the aid of the Stata IC 14 software.

\section{PRESENTATION AND DISCUSSION OF RESULTS}

Initially, the database contained 551 companies (5,862 observations), of which 95 (17.24\%) held shareholders' agreements. After the exclusion of the Finance and Insurance sector and companies with negative equity, the final composition of the sample was formed by 472 companies $(4,303$ observations), of which $86(18.22 \%)$ with agreements.

Throughout the period under review, the general average of control exercised by the largest shareholder is $56.9 \%$, however, when we consider the percentage of indirect control formed through related shares, there is an increase of $8 \%$ reaching the $61.2 \%$ mark, evidencing even more the characteristic of concentrated ownership of the Brazilian market.

In general, in a direct manner $61 \%$ of the sample has a controlling shareholder. However, when taking into account related shares, there is an increase of $11 \%$, comprising $68 \%$ of the sample. This result indicates that the pulverization of capital in the Brazilian market may, 
to some extent, be associated with the maintenance of indirect control through the use of these contracts. This is the case, for example, of the company Positivo Informática whose shareholder agreement (from the year 2007) is formed by the 4 largest partners. Positivo has its ownership structure categorized as pulverized, since the largest shareholder has only $14 \%$ of the common shares. However, when considering the shareholder agreement, the formed group holds $70.5 \%$ of the shares. Therefore, indirectly the company has a controlling group.

Regarding the periodicity with which the agreements provided a group of shareholders to obtain control of the company throughout the analyzed period, 386 occurrences were registered (52\%). Maintenance was frequent in $45.8 \%$ of the observations. This is the case of Ambev, a food and beverage company whose controlling shareholder, even having a stake of approximately $53 \%$, is part of the group of related shares increased its control to $71.5 \%$.

As for defense agreements, they are still rare in Brazil. They appear in only $2.2 \%$ of observations. One example is the company Saraiva Booksellers. The defense agreement is composed of a group of four shareholders who are members of the company's founding family. The percentage of control formed by the group is of $20.05 \%$, so that it is already possible to elect members in the board of directors, ensuring that some interests are taken into account in the firm's strategic decisions.

Regarding the SAI, the average result is 9.07 points with a standard deviation of approximately 3 points. Regarding the lowest evaluation found, of 1 point, obtained by the company Linx, from the Software and Data sector, only in the year of 2013. Companies recognized in the capital market such as BR Foods and Natura obtained 5.6 and 7 points respectively in at least one of the analyzed period. On the other hand, the maximum score of 16 was reached by Braskem. Other companies such as: Ambev, Vale, Cielo and JBS Friboi scored higher than 12 points.

To obtain a more accurate perception of how Brazilian companies use the shareholders agreements, Table 5 gives the mean of each of the five dimensions investigated. As for the first dimension, the average result was 3.76, the highest we found. The second dimension, whose objective is the restriction of the reduction of the payment of dividends, obtained an average result of 0.32 (we emphasize that it is composed of only one question, therefore, it can vary from 0 to 1 ). The third, the dimension relating to investment clauses, and the fourth, financing, presented a score of 1.55 and 0.86 respectively. On the other hand, corporate governance, whose clauses that encourage the expropriation of minority shareholders were the most frequent in most agreements, presented the average result of 2.56 points.

Table 5. Means of the Five Dimensions of the SAI

\begin{tabular}{lcc}
\hline Dimension & Score Achieved & (Score Scale) \\
\hline SAI & 9.07 & $0-24$ \\
1. Transfer of shares & 3.76 & $0-6$ \\
2. Dividend & 0.32 & $0-1$ \\
3. Investment & 1.55 & $0-5$ \\
4. Financing & 0.86 & $0-3$ \\
5. Corporate Governance & 2.56 & $0-9$ \\
\hline
\end{tabular}
Source: Research Data

\subsection{RESULTS OF MODELS}

Model 1 aims to test both hypotheses. The results are presented in Table 6. 
BBR

15,1

98

Table 6. Model 1 Results

\begin{tabular}{|c|c|c|c|}
\hline \multirow{2}{*}{ Variables } & \multirow{2}{*}{$\begin{array}{c}\text { Hypothesis } 1 \\
\text { (1) }\end{array}$} & \multicolumn{2}{|c|}{ Hypothesis 2} \\
\hline & & $(2)$ & (3) \\
\hline \multirow{2}{*}{ Agree $^{*}$ Avot } & 0.0785 & & \\
\hline & $(0.407)$ & & \\
\hline \multirow{2}{*}{ Avot } & 0.391 & & \\
\hline & $(0.254)$ & & \\
\hline \multirow{2}{*}{ Agree } & 5.254 & $18.40^{* *}$ & \\
\hline & $(27.42)$ & (9.158) & \\
\hline \multirow{2}{*}{ Sai } & & & $1.932^{* *}$ \\
\hline & & & $(0.961)$ \\
\hline \multirow{2}{*}{ Vot } & & 0.332 & 0.329 \\
\hline & & $(0.251)$ & $(0.251)$ \\
\hline \multirow{2}{*}{ Leverage } & $0.562^{* * *}$ & $0.562^{* * *}$ & $0.562^{* * *}$ \\
\hline & $(0.137)$ & $(0.137)$ & $(0.137)$ \\
\hline \multirow{2}{*}{ Roa } & $1.152^{* * *}$ & $1.151^{* * *}$ & $1.153^{* * *}$ \\
\hline & $(0.336)$ & $(0.336)$ & $(0.336)$ \\
\hline \multirow{2}{*}{ Ltotassets } & $28.25^{* * *}$ & $27.85^{* * *}$ & $27.98^{* * *}$ \\
\hline & $(4.520)$ & $(4.472)$ & $(4.486)$ \\
\hline \multirow{2}{*}{$A d r$} & 37.87 & 36.50 & 36.39 \\
\hline & $(25.11)$ & $(25.29)$ & $(25.02)$ \\
\hline \multirow{2}{*}{ Ibovespa } & $0.187^{* * *}$ & $0.187^{* * *}$ & $0.186^{* * *}$ \\
\hline & $(0.0250)$ & $(0.0250)$ & $(0.0250)$ \\
\hline \multirow{2}{*}{ Constant } & $-257.5^{* * *}$ & $-248.4^{* * *}$ & $-249.8^{* * *}$ \\
\hline & $(63.62)$ & $(62.69)$ & $(62.68)$ \\
\hline Observations & 3,493 & 3,493 & 3,493 \\
\hline Firms & 434 & 434 & 434 \\
\hline R-within & 0.095 & 0.094 & 0.094 \\
\hline R-between & 0.017 & 0.017 & 0.017 \\
\hline $\mathrm{R}$ - overall & 0.038 & 0.038 & 0.038 \\
\hline rho & 0.668 & 0.667 & 0.667 \\
\hline Firm Fixed Effect & YES & YES & YES \\
\hline
\end{tabular}

With respect to Hypothesis 1, the interaction between the indirect ownership structure and the presence of agreements was inconclusive, that is, without statistical significance. Therefore, the argument that the increase in firm value would be related to the reorganization of power, measured through the related actions, was not consistent, a result consistent with Volpin (2002), Belot (2008), Villalonga and Amit (2009) and Baglioni (2011). We therefore reject hypothesis 1.

On the other hand, the results obtained point to the confirmation of Hypothesis 2 . Therefore, the presence of shareholders' agreements (agree) presented a $\beta$ coefficient of 18.40 ( $p$-value $<5 \%$ ). It is understood, therefore, that the market value of companies with shareholders' agreement is $18 \%$ higher. Results similar to those obtained by Roosenboom and Schramade (2006).

In addition, when the SAI is introduced into the model, on average, for an increase of 1 point of SAI we obtain approximately a MB $2 \%$ higher, since the results indicate a $\beta$ coefficient of 1.93 ( $p$-value $<5 \%$ ). This effect at first seems inexpressive. However, when considering the average SAI value of 9.07 points, the impact on the market value of the firm is approximately $16.52 \%$. Result which is consistent with the hypothesis that the greater the capacity of shareholders' agreements to mitigate the expropriation of minority shareholders, the greater the effect on the firm's value. Argument in line with Chemla et al (2007) and Carvalhal (2012). 
In view of the confirmation of Hypothesis 2 obtained by the tests developed with Model

1 , we performed additional tests by decomposing each dimension of the SAI. We therefore try to verify the effect that each of the dimensions singly causes in the value of the firm (from Test 1 to 5), as well as in conjunction (Test 6).

Table 7 presents the tests performed. With regard to the dimensions we tested independently, only investment (aci) and corporate governance (Acgc) were statistically significant $(\beta=8.13$ and $\beta=7.29$ with $p$-value $<5 \%$ respectively). On the other hand, when analyzed together, the only dimension that presented consistency was corporate governance $(a c g c)$; In addition, we emphasize that the intensity provoked in the value of the firm is greater than that obtained in the SAI ( $p$-value $<5 \%$ ). Therefore, We understand that 1 point in the dimension of corporate governance has an average effect of $9.72 \%$ in the value of the firm. Thus, considering the average value obtained by companies in this dimension, the effect would be $25 \%$.

Table 7. Model 2 Results

\begin{tabular}{|c|c|c|c|c|c|c|}
\hline \multirow[t]{2}{*}{ Variables } & Transfer of shares & Dividend & Investment & Financing & $\begin{array}{l}\text { Corporate } \\
\text { Governance }\end{array}$ & All Dimensions \\
\hline & (1) & (2) & (3) & (4) & $(5)$ & (5) \\
\hline \multirow{2}{*}{ Act } & 3.194 & & & & & -3.488 \\
\hline & $(2.037)$ & & & & & $(3.144)$ \\
\hline \multirow{2}{*}{ Acd } & & 11.81 & & & & -8.247 \\
\hline & & $(14.67)$ & & & & $(20.55)$ \\
\hline \multirow{2}{*}{$A c i$} & & & $8.137^{* *}$ & & & 14.39 \\
\hline & & & $(4.107)$ & & & (9.719) \\
\hline \multirow{2}{*}{ Acf } & & & & 5.067 & & -17.49 \\
\hline & & & & (6.197) & & (12.28) \\
\hline \multirow{2}{*}{$\operatorname{Acgc}$} & & & & & $7.291^{* *}$ & $9.776^{* *}$ \\
\hline & & & & & $(2.992)$ & $(4.411)$ \\
\hline \multirow{2}{*}{ Vot } & 0.315 & 0.301 & 0.322 & 0.297 & 0.336 & 0.350 \\
\hline & $(0.250)$ & $(0.247)$ & $(0.252)$ & $(0.248)$ & $(0.252)$ & $(0.256)$ \\
\hline \multirow{2}{*}{ Leverage } & $0.563^{* * *}$ & $0.564^{* * *}$ & $0.563^{* * *}$ & $0.564^{* * *}$ & $0.561^{* * *}$ & $0.560^{* * *}$ \\
\hline & $(0.138)$ & $(0.138)$ & $(0.138)$ & $(0.138)$ & $(0.137)$ & $(0.137)$ \\
\hline \multirow{2}{*}{ Roa } & $1.150^{* * *}$ & $1.149^{* * *}$ & $1.147^{* * *}$ & $1.146^{* * *}$ & $1.154^{* * *}$ & $1.145^{* * *}$ \\
\hline & $(0.336)$ & $(0.336)$ & $(0.335)$ & $(0.337)$ & $(0.337)$ & $(0.336)$ \\
\hline \multirow{2}{*}{ Ltotassets } & $28.14^{* * *}$ & $28.73^{* * *}$ & $28.12^{* * *}$ & $28.53^{* * *}$ & $28.11^{* * *}$ & $28.16^{* * *}$ \\
\hline & $(4.504)$ & $(4.464)$ & $(4.467)$ & $(4.481)$ & $(4.466)$ & $(4.542)$ \\
\hline \multirow{2}{*}{$A d r$} & 29.83 & 27.04 & 33.31 & 26.36 & 38.28 & 35.96 \\
\hline & $(24.42)$ & $(26.50)$ & $(25.07)$ & $(25.11)$ & $(24.34)$ & $(25.72)$ \\
\hline \multirow{2}{*}{ Ibovespa } & $0.186^{* * *}$ & $0.185^{* * *}$ & $0.186^{* * *}$ & $0.185^{* * *}$ & $0.186^{* * *}$ & $0.187^{* * *}$ \\
\hline & $(0.0250)$ & $(0.0250)$ & $(0.0250)$ & $(0.0250)$ & $(0.0249)$ & $(0.0249)$ \\
\hline \multirow{2}{*}{ Constant } & $-249.3^{* * *}$ & $-254.4^{* * *}$ & $-249.8^{* * *}$ & $-251.5^{* * *}$ & $-252.2^{* * *}$ & $-252.9^{* * *}$ \\
\hline & $(62.84)$ & $(62.78)$ & $(62.67)$ & $(62.72)$ & $(62.71)$ & $(63.77)$ \\
\hline Observations & 3493 & 3493 & 3493 & 3493 & 3493 & 3493 \\
\hline Firms & 434 & 434 & 434 & 434 & 434 & 434 \\
\hline R-within & 0.09 & 0.091 & 0.093 & 0.091 & 0.094 & 0.094 \\
\hline R-between & 0.01 & 0.015 & 0.016 & 0.016 & 0.019 & 0.019 \\
\hline R- overall & 0.03 & 0.037 & 0.039 & 0.039 & 0.040 & 0.040 \\
\hline rho & 0.66 & 0.667 & 0.668 & 0.665 & 0.667 & 0.667 \\
\hline Firm Fixed Effect & YES & YES & YES & YES & YES & YES \\
\hline
\end{tabular}


BBR

15,1

100

\section{CONCLUSION}

This research is based on the new perspective of corporate governance, whose agency problems emerge from the relationship between controlling shareholders and minority shareholders. In this context, this paper intends to investigate the effect of these agreements on the market value of Brazilian firms. Considering the direct ownership structure, fixedeffects regressions provide evidence that the use of shareholders' agreements is associated with the increase in firm value, being consistent with Roosenboom and Schramade (2006) and Carvalhal (2012).

However, the presence of shareholders' agreements alone is insufficient to understand the effect of these contracts. The SAI was then introduced. In line with Chemla et al. (2007) and, in particular, with Carvalhal (2012), the results show that the effect on the value of the firm is positive as it increases the ability of the shareholder agreement on mitigating the expropriation of minority shareholders and, therefore, when there is an increase in the value of the SAI, according to Chemla et al (2007) and in particular, with Carvalhal (2012).

Furthermore, additional tests conducted separately with each of the dimensions that make up the SAI increase the evidence that the redistribution of power could be associated with certain characteristics of the clauses that make up the agreements, because only two of them obtained statistical significance (the investment dimension and the corporate governance dimension).

On the other hand, the regressions carried out with the indirect OS and the presence of the agreements were not able to provide indications to that effect. All the tests we performed were inconsistent. Therefore, we can infer that the reorganization of the power obtained through the block of shareholders signatories of the agreement did not present evidence of being associated with the increase of the value of the firm.

Regarding the main limitations perceived during the development of this study, these are mainly related to the database. Firstly, there is no standardization with regard to the information contained in the agreements, a fact that makes data collection difficult, so that the interpretation of the clauses and, later, their categorization are associated with the subjectivity of the researcher. In addition, there is a difficulty in measuring indirect OS, because in most agreements it is not informed what is the percentage of its members' shares in the firm's OS.

The main suggestion for future research is related to the investigation of the inclusion of companies in different institutional contexts, given that the results in this study suggest that SAs play an even more important role in markets with low legal protection with a high level of concentrated OS. However, such institutional differences may result in different practices, regarding the use of such contracts.

\section{PARTICIPATION OF AUTHORS}

Author 1: Author 1 participated in the research problem definition steps, development of hypotheses, theoretical framework, methods and results, data collection and statistical analysis, data analysis and interpretation, writing and revision of the manuscript.

Author 2: Author 2 participated in the steps of defining the methods and results, interpretation of data, writing and revision of the manuscript.

Author 3: Author 3 participated in the steps of defining the research problem, development of hypotheses, theoretical framework, methods and results, statistical analysis, interpretation of data and revision of the manuscript. 


\section{REFERENCES}

BAGLIONI, Angelo. Shareholders' agreements and voting power: Evidence from Italian listed firms. Applied Economics, v. 43, p. 4043-4052, 2011.

BELOT, François. Shareholder agreements and firm value: Evidence from French listed firms. Université de Cergy-Pontoise Working Paper No. 1282144, October, 2008.

BERLE, Adolf A.; BERLE, Means, GARDINER C. Modern corporations and private property. New York: Macmilliam, 1932.

CARVALHAL, Andre. Do shareholder agreements affect market valuation? Evidence from Brazilian listedfirms. Journal of Corporate Finance, v. 18, p. 919-933, 2012.

CARVALHOSA, Modesto. Comentários à Lei de Sociedades Anônimas. 3. ed. São Paulo: Saraiva, v. 2, 2003.

CHEMLA, Gilles; LJUNGQVIST, Alexander; HABIB, Michel A. An analysis of shareholder agreements. Journal of the European Economic Association, v. 5, n. 1, p. 93-121, 2007.

CLAESSENS, Stijn; DJANKOV, Simeon; LANG, Larry H. P. The separation of ownership and control in East Asian Corporations. Journal of Financial Economics, v. 58, p. 81-112, 2000.

CLAESSENS, Stijn.; DJANKOV, Simeon.; JOSEPH, Fan, P. H.; LANG, Larry. H. P. Disentangling the incentive and entrenchment effects olarge shareholdings, v. 57, n. 6, p. 2741-2771, 2002.

CLAESSENS, Stijn; FAN, Joseph P. H. Corporate governance in Asia: A survey. International Review of Finance, v. 3, n. 2, p. 71-103, 2002.

DENIS, Diane K.; MCCONNEL, John J. International corporate governance. Journal of Financial \& Quantitative Analysis, v. 38, n. 1, p. 1-36, 2003.

DOUMA, Sytse; GEORGE, Rejie; KABIR, Rezaul. Foreign and domestic ownership, business groups, and firm performance: evidence from a large emerging market. Strategic Management Journal, v. 27, p. 637$657,2006$.

FACCIO, Mara; LANG, Larry H.; YOUNG, Leslie. Dividends and expropriation. American Economic Review, v. 91, n. 1, p. 54-78, 2001.

FAMA, Eugene F.; JENSEN, Michael C. Separation of ownership and control. Journal of Law and Economics, v. 26, n. 2, p. 301-325, 1983.

FILATOTCHEV, Igor; KAPELYUSHNIKOV, Rostislav; DYOMINA, Natalya; AUKUTSIONEK, Sergey. The effects of ownership concentration on investment and performance in privatized firms in Russia. Managerial \& Decision Economics, v. 22, n. 6, p. 299-313, 2001.

FILHO, Celso B. Acordo de acionistas: panorama atual do instituto no direito brasileiro e propostas para a reforma de sua disciplina legal. Revista de Informação Legislativa, v. 38, n. 152, p. 243-267, 2001.

GIANFRATE, Gianfranco. What do shareholders' coalitions really want? Evidence from Italian voting trusts. Corporate Governance: An International Review, v. 15, n. 2, p. 122-132, 2007.

HAIR, Joseph F. JR; BLACK, William C.; BABIN, Barry; ANDERSON, Rolph E., TATHAM, Ronald L. Análise multivariada de dados. 6. ed. Porto Alegre: Bookman, 2009.

HLOUSKOVA, J., and M. WAGNER. The performance of panel unit root and stationarity tests: Results from a large scale simulation study. Econometric Reviews, v. 25, p. 85-116, 2006.

IM, K. S., M. H. PESARAN, and Y. SHIN. Testing for unit roots in heterogeneous panels. Journal of Econometrics, v. 115, p. 53-74, 2003.

JENSEN, Michael C. Organization theory and methodology. The Accounting Review, v. 58, n. 2, p. 319-339, 1983.

JENSEN, Michael. C.; MECKLING, William. Theory of the firm: managerial behavior, agency costs and ownership structure. Journal of Financial Economics, v. 3, n. 4, p. 305-306, 1976.

JOHNSON, Simon; LA PORTA, Rafael; LOPEZ DE SILANES, Florencio; SHLEIFER, Andrei. Tunnelling. American Economic Review, v. 90, n. 2, p. 22-27, 2000.

LA PORTA, Rafael; LOPES-DE-SILANES, Florencio S; SHLEIFER, Andrei. Corporate ownership around the world. The Journal of Finance, v. 54, n. 2, p. 471-517, 1999.

LA PORTA, Rafael; LOPEZ-DE-SILANES, Florencio; SHLEIFER, Andrei; VISHNY, Robert W. Legal determinants of external finance. The Journal of Finance, v. 52, n. 3, p. 1131-1150, 1997.

LA PORTA, Rafael; LOPEZ-DE-SILANES, Florencio; SHLEIFER, Andrei; VISHNY, Robert W. Investor protection and corporate valuation. The Journal of Finance, v. 52, n. 3, p. 1147-1170, 2002.

LEAL, Ricardo P. C.; SILVA, André C. Controle compartilhado e o valor das empresas brasileiras. RACEletrônica, v. 2, n. 2, p. 296-310, 2008.

MORCK, Randall; SHLEIFER, Andre; VISHNY, Robert W. Management ownership and market valuation an empirical analysis. Journal of Financial Economics, v. 20, p. 293-315, 1988.
BBR

15,1

101 
ROOSENBOOM, Peter; SCHRAMADE, Willem. The price of power: Valuing the controlling position of owner-managers in French IPO firms. Journal of Corporate Finance, v. 12, p. 270-295, 2006.

SHLEIFER, Andrei; VISHNY, Robert W. Large Shareholders and Corporate Control. Journal of Political Economy, v. 94, n. 3, p. 461-488, 1986.

SHLEIFER, Andrei; VISHNY, Robert W. A survey of corporate governance. The Journal of Finance, v. 52, n. 2, p. 737-833, 1997.

SILVA, André, L. Governança corporativa, valor, alavancagem e política de dividendos das empresas brasileiras. Revista de Administração - RAUSP, v. 39, n. 4, p. 348-361, 2004.

SILVEIRA, A. D. M.(C). Governança Corporativa e a Estrutura de Propriedade Determinantes e Relação com o Desempenho das Empresas no Brasil. 2004. 250 f. Tese (Doutorado em Administração) - Faculdade de Economia, Administração e Contabilidade - Universidade de São Paulo, São Paulo, 2004.

VILLALONGA, Belen; AMIT, Raphael. H. How are U.S.family firms controlled? The Review of Financial Studies, v. 22, n. 8, p. 3047-3091, 2009.

VOLPIN, Paolo. Governance with poor investor protection: Evidence from top executive turnover in Italy. Journal of Financial Economics, v. 64, p. 61-90, 2002.

YOUNG, Michael N.; PENG, Mike W; AHLSTROM, David; BRUTON, Garry D.; JIANG, Yi. Corporate governance in emerging economies: a review of the principal-principal perspective. Journal of Management Studies, v. 45, n. 1, p. 196-220, 2008. 


\section{ANNEXES AND APPENDIX}

\section{AnNex A - SAI Development Questionnaire}

Table 8. Questionnaire for forming the Quality Index of the Shareholder Agreement - SAI

\begin{tabular}{|c|c|}
\hline Dimension & 1code \\
\hline 1. Transfer of shares & ACT \\
\hline 1. Does the agreement contain no preemptive right? & ACT1 \\
\hline 2. Does the agreement contain no put options? & ACT2 \\
\hline 3. Does the agreement contain no purchase options? & АCT3 \\
\hline 4. Does the agreement not contain the tag-along right? & ACT4 \\
\hline 5. Does the deal not include the drag-along right? & ACT5 \\
\hline 6. Does the agreement not restrict the transfer of shares? & ACT6 \\
\hline 2. Dividend & $\mathrm{ACD}$ \\
\hline 7. Does the agreement restrict the decrease in dividend payments? & ACD1 \\
\hline 3. Investment & $\mathrm{ACI}$ \\
\hline 8. Does the deal prohibit operations that go beyond corporate goals? & ACI1 \\
\hline 9. Does the agreement restrict certain mergers and acquisitions? & ACI2 \\
\hline 10. Does the agreement impose limits and restrictions on investments? & $\mathrm{ACI} 3$ \\
\hline 11. Does the agreement restrict the sale of assets? & ACI 4 \\
\hline 12. Does the agreement prohibit competition with the company itself? & $\mathrm{ACI} 5$ \\
\hline 4. Financing & $\mathrm{ACF}$ \\
\hline 13. Does the agreement restrict indebtedness? & ACF1 \\
\hline 14. Does the agreement restrict the issue of shares at preferential prices? & ACF2 \\
\hline 15. Does the agreement prohibit collateralisation in obtaining third-party capital? & ACF3 \\
\hline 5. Corporate Governance & ACGC \\
\hline 16. Does the agreement establish the executive compensation system? & ACGC1 \\
\hline 17. Does the agreement restrict related party transactions? & ACGC2 \\
\hline 18. Does the agreement set the criteria for the appointment of independent auditors? & ACGC3 \\
\hline 19. Does the agreement establish conflict resolution through arbitration? & ACGC4 \\
\hline 24. Does the agreement establish other types of governance mechanisms? & ACGC5 \\
\hline 20. Does the agreement not restrict the freedom of board members in appointing the CEO? & ACGC5 \\
\hline 21. Does the agreement not restrict shareholders' freedom to appoint board members? & ACGC6 \\
\hline 22. Does the agreement not restrict the counselors' votes in preliminary meetings? & ACGC7 \\
\hline 23. Does the agreement not restrict shareholder votes in preliminary meetings? & ACGC8 \\
\hline 24. Does the agreement establish other positive corporate governance clauses? & ACGC 9 \\
\hline
\end{tabular}


BBR

15, 1

104

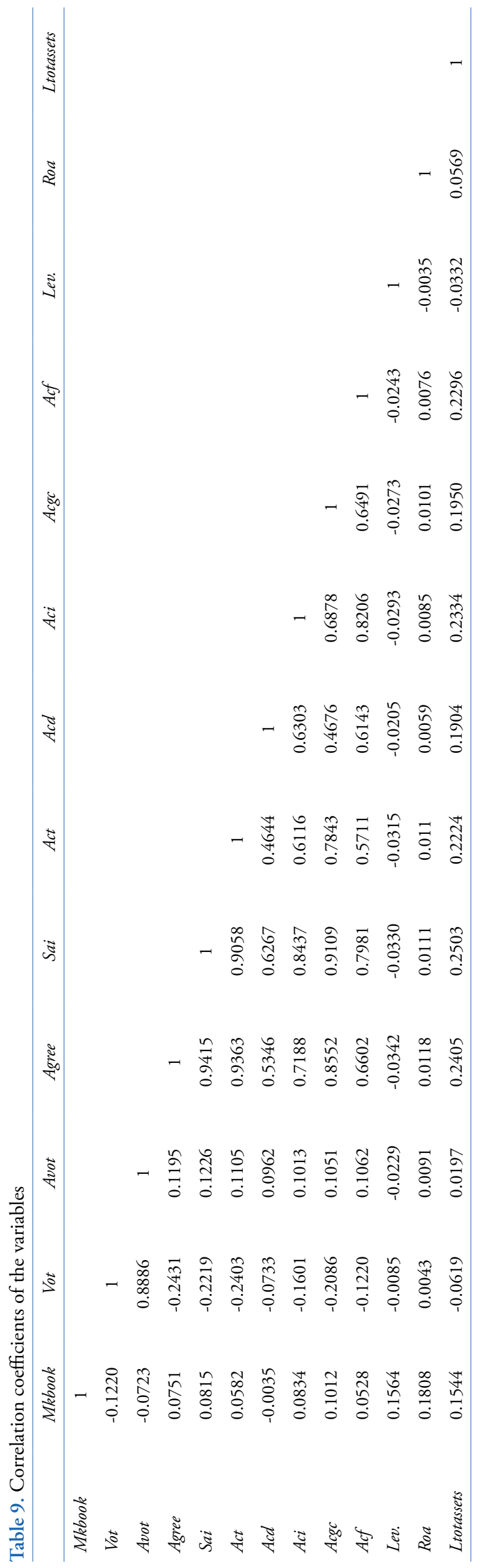

